\title{
DỨcin
}

Technological University Dublin

ARROW@TU Dublin

Articles

School of Food Science and Environmental

Health

2017-08-17

\section{Dietary Phytochemicals as Inhibitors of Primary Amine Oxidase}

\author{
Padraig Shanahan \\ Technological University Dublin, padraigshanahan@icloud.com \\ Jeffrey O'Sullivan \\ Trinity College Dublin, Ireland, JOSULLI@tcd.ie \\ Keith F. Tipton \\ Trinity College Dublin, Ireland, ktipton@tcd.ie
}

See next page for additional authors

Follow this and additional works at: https://arrow.tudublin.ie/schfsehart

Part of the Biochemistry Commons, Molecular Biology Commons, and the Other Biochemistry, Biophysics, and Structural Biology Commons

\section{Recommended Citation}

Shanahan, P., O'Sullivan J., Tipton, K.F., Kinsella, G., Ryan, B.J. and Henehan, G.T. (2017). Dietary phytochemical inhibitors of primary amine oxidase. Journal of Biotechnology, 256, S96-S97, 2017. doi.org/10.1016/j.jbiotec.2017.06.1130

This Article is brought to you for free and open access by the School of Food Science and Environmental Health at ARROW@TU Dublin. It has been accepted for inclusion in Articles by an authorized administrator of ARROW@TU

Dublin. For more information, please contact

arrow.admin@tudublin.ie, aisling.coyne@tudublin.ie, gerard.connolly@tudublin.ie.

Funder: DIT Fiosraigh Scholar (PS)

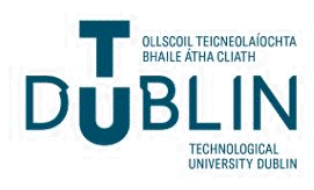




\section{Authors}

Padraig Shanahan, Jeffrey O'Sullivan, Keith F. Tipton, Gemma Kinsella, Barry J. Ryan, and Gary T. Henehan 


\section{Dietary phytochemicals as inhibitors of primary amine oxidase}

2 P. Shanahan ${ }^{1}$, J O'Sullivan ${ }^{2}$, KF Tipton ${ }^{3}$, GK Kinsella ${ }^{1}$, B Ryan ${ }^{1}$, GTM. Henehan ${ }^{1}$

3 1. Applied Enzymology Group, Food Science and Environmental Health, Dublin Institute of Technology, Dublin 1, Ireland.

$4 \quad$ 2. School of Dental Sciences, Trinity College Dublin, Dublin, Ireland.

5 3. School of Biochemistry and Immunology, Trinity College Dublin, Dublin, Ireland.

6 Phytochemicals such as methylxanthines, catechins and polyphenols show health benefits in a range

7 of diseases although their mechanism of action is not fully understood. Primary Amine Oxidase

8 (PrAO) is widely recognised as a therapeutic drug target for the treatment of inflammatory, vascular

9 and neurodegenerative diseases. Previous work in our laboratories showed that caffeine inhibited

10 bovine PrAO activity with a $\mathrm{Ki}$ of $1.0 \mathrm{mM}$. In the present study we examined a range of

11 methylxanthines and catechins as inhibitors of bovine PrAO. The methylxanthines tested were

12 caffeine, paraxanthine, theophylline, theobromine and 7-methylxanthine. Of these, only theobromine was an inhibitor with an IC50 of $c a .300 \mu \mathrm{M}$. Calculations indicated that theobromine in foods could inhibit PrAO activity by $20 \%$. The effect of dietary catechins; epicatechin, epicatechin gallate and epigallocatechingallate was even more significant with IC50 values in the micromolar region. However, inhibition by catechins was complicated by apparent activation of PrAO at high concentrations although this was not significant at physiologically attainable levels. Nonetheless, these findings indicate that a range of dietary phytochemicals could affect PrAO activity in vivo. We suggest that the health benefits associated with consumption of certain phytochemicals may be attributed to PrAO inhibition. 